\title{
SWOT Analysis of King Abdullah II School for Information Technology at University of Jordan According to Quality Assurance Procedures
}

\author{
http://dx.doi.org/10.3991/ijac.v6i1.2041 \\ Lubna M. Nasir Eddeen, Ansar Magdalena H. Khoury, \\ Osama K. Harfoushi, Itaf Abu Shanab, Nabeel M. M. Alassaf \\ University of Jordan, Amman, Jordan
}

\section{INTRODUCTION}

Many books and research papers have defined and referred to the term SWOT Analysis. But according to [11], SWOT Analysis can be defines as "strategic planning method used to evaluate the Strengths, Weaknesses, Opportunities, and Threats involved in a project or in a business venture". It's used to assess internal and external environmental factors which affect on the business. It first appeared in the 70's when some companies started to collapse in order to understand the reasons behind these failings. This method was created by a research project at Stanford University from 1960s -1970s. SWOT Analysis is illustrated in Figure-1 [2]. There are two attributes of the organization used to assess internal factors: Strengths that helpful in achieving the objective, while Weaknesses are harmful to achieving the objective. On the other hand, the other dimensions use to assess external factors: Opportunities are external conditions that are helpful to achieving the objective, while Threats could do damage to the business's performance [11].

\section{SWOT ANALYSIS}

TABLE I.

ILLUSTRATIVE DIAGRAM OF SWOT ANALYSIS.

\begin{tabular}{|c|c|c|}
\hline & $\begin{array}{c}\text { Helpful } \\
\text { in achieving the } \\
\text { objective }\end{array}$ & $\begin{array}{c}\text { Harmful } \\
\text { in achieving the } \\
\text { objective }\end{array}$ \\
\hline $\begin{array}{c}\text { Internal } \\
\text { Origin }\end{array}$ & Strengths & Weaknesses \\
\hline $\begin{array}{c}\text { External } \\
\text { Origin }\end{array}$ & Opportunities & Threats \\
\hline
\end{tabular}

SWOT analysis can be used in many fields of study; industry, management, engineering, and also in education (which is the study field of this paper). For example, University of Huston - Victoria [9] has used SWOT analysis to improve the growth of the university. The university produced set of annual reports of SWOT Analysis for the performance of its system during the period 2004 till 2010. SWOT analysis helped the university to find its strength points and opportunities which will contribute to the growth of the university; it also helped the university to realize its weaknesses which should be eliminated to make the growth successful.

SWOT analysis was also used to improve MIS curriculum at Midwest University, according to Stapleton [6]. The main impact of the SWOT analysis was to determine the course offerings and course content to provide the students with the skills required and competitive advantage for employment. The SWOT analysis was performed according to:

1. Survey which was delivered to a group of alumni that had graduated within 5 or 10 years, and occupied a job in 18 different companies. They were asked about different subjects and skills taught in the department and their usage in the performance of their daily tasks. The skill ranking addressed several aspects regarding the importance of each skill towards MIS curriculum.

2. Interview process in which 4 employees were chosen to participate. These employees represented a diverse set of industry sectors: Banking, Food processing, Electrical utilities, and Insurance. Each employee was asked a series of questions regarding the topics on: Technical skills, Personal skills and Current projects.

This paper focuses on the all departments of King Abdullah II School for Information Technology (KASIT) in University of Jordan. First, CS department was established in 1985 within the Faculty of Science as a separate department to satisfy the need for specialized graduates in Computer Science. In the implementation of the new trends of the government of Hashemite Kingdom of Jordan in order to make Jordanian citizens IT literate, University of Jordan established King Abdullah II School for Information Technology (KASIT) in 2000/2001 in four programs of interest: Computer Science (CS), Computer Information Systems (CIS), Business Information Systems (BIS), and finally in 2007/2008 Graduate (M. Sc.) program in CIS has appeared. These departments were established to meet the needs of industry locally and internationally.

One main trouble with applying SWOT analysis in a certain company is that while it works on the four elements associated with the organizational and environmental analysis, it does not deal with how the company can identify the elements for this particular company [4]. Many managers may not be able to determine what these elements are, and SWOT does not give any assistance in this aspect. So, Quality Assurance (QA) Procedures were 
followed in this study to specify the main elements to be examined.

According to [10] and [11], Quality Assurance (QA) can be defined as "the planned and systematic production processes that provide confidence in a product's suitability for its intended purpose". It is a set of activities intended to ensure that system components satisfy the intended requirements in a systematic, reliable way. QA principles can be applied in wide variety of fields such as; manufacturing, civil engineering, mass products, software development, and finally company quality. It appears that QA approach is therefore not limited to the manufacturing only but can be extended to any business or non-business activity. For example: Design work, Administrative services, Consulting, Banking, Insurance, Computer software development, and Education. This paper focuses on the last activity, which is Education. The Quality Assurance Agency for Higher Education (QAA) was established in 1997 to provide an integrated quality assurance service for United Kingdom higher education [7].

Therefore, the purpose of Quality Assurance is to improve and maintain the quality of education. According to KASIT, a subject review method was used in which there are various aspects impact on the standard and quality of education that is related to operations and functions [7]. These aspects can be listed as: Curriculum Design, Content and Organization (CDCO), Teaching / Learning and Assessment (TLA), Students' Admission and Progression (SAP), Student Support and Guidance (SSG), Learning Resources (LR), finally Quality Management and Enhancement (QME). These aspects were formulated after revising the Institutional audit that was operated in England and Northern Ireland in 2011 [3]. These aspects can be summarized as follows:

1. CDCO: The concern of this aspect is the curriculum structure with the course description and the usefulness of the curriculum.

2. TLA: is concerned with the process of assessing the teaching of staff and learning of students.

3. SAP: this aspect focuses on acceptance and registration rules for citizens \& foreign students.

4. SSG: it is a systematic mechanism to offer support and advice for students at each academic year. In addition, to easy the communication between students through making graduation projects to gain work experience and enhance their employability. Also, to introduce facilitation of the movement for disabled students, and finally, to employ qualified persons to help disabled students.

5. LR: it includes libraries, Journals, E-Libraries, professional tools or activities, teaching rooms, labs, and some elements of students support. The objective here is to enhance and promote the high quality in teaching and learning process.

6. QME: it is the system built to supervise and improve the quality of services delivered by the organization leading to Quality Assurance (QA) notations. The objective here is to guarantee for the stakeholders of such organization that it will provide a-certain level of quality. It is meant here the quality of its services, which must be high and consistent in according to a set of realistic references. It also aims to fulfill the Vision, Mission, Aims, Objectives and Quality
Policies of the organization. And all of this will be achieved by considering QME as a self developing system.

\section{KASIT CRITERIA}

After reviewing the overall aspects provided in the official website of JU [8], these aspects are provided in terms of the university, KASIT, and its three departments policies respectively. When referring to QA procedures whose characteristics are summarized in an electronic portfolio of learning obtained from learning atmosphere [1], KASIT criteria was built by the specialized QA committees at three levels: department, faculty, and University. KASIT criteria can be summarized as follows:

1. CDCO: is concerned with the curriculum structure with the course description and the usefulness of the curriculum. This aspect focuses on: Curriculum map, syllabuses, KASIT over plan, Curriculum for B.Sc. in all departments in KASIT which is developed every five years. Also supervisory plan is given to each first-year student in the department. Feedback from the local private and public sectors companies helps to draw the main lines of the newly developed study plan. Graduation projects and master thesis have contributed to the solutions of many problems in the local and global societies. Evaluation of both instructors and taught topics, meeting with students, and ETS and GET Exams all give a feedback about the development of the learning and teaching process in all departments in KASIT.

2. TLA: is concerned with the process of assessing the teaching of staff and learning of students. It consists of the following criteria aspects: staff list, building map, computer labs, blackboard site, special needs evidences, hardware, software \& resources, workshops, training, graduation project and ILO's forms listed in the main page of KASIT website in [8].

3. SAP: it focuses on acceptance and registration rules for citizens \& foreign students, special needs students, graduation students, university e-mails, and students' affairs.

4. SSG: it is a systematic mechanism to offer support and advice for students at each academic year, through the existence of registration advisor. This advisor, who is an academic staff, is specified for each student when he first registers in his department. In addition, to ease the communication between students working in groups is required in the graduation projects. In addition, an electronic Plasma Board is used to announce any important information for students, like: exams' schedule, list of forbidden student, important dates for students, etc... Also, to introduce facilitation of the movement for disabled students. Finally, to employ qualified persons to help disabled students.

5. LR: In KASIT, the human resources are shared by the three departments of the School. Each department in KASIT has his own faculty members, both $\mathrm{PhD}$ and MSc holders, teaching assistants, and a number of Part-time staff members. KASIT also provides the following Learning Resources: KASIT Computer Labs, The Computer Centre, Software Packages and Manuals, Online Courses, Blackboard facility, KASIT Library, The Main Library of JU, E-Library, 
Textbooks and references, Assistance Points (like Dean's Office, staff offices, secretary offices, a room for M. Sc. students (Teaching Assistants) and rooms for part-timers, Teaching rooms, Administrative and Teaching Resources (Xerox-machines, data shows, laptops, and smart boards), and The Centre of Consultations and Technical Services and Study.

6. QME: this aspect deals with university regulations stated to ensure rational quality. All departments in KASIT department also have a strong construction, where specialized committees undertake a thorough study for the various aspects controlled by Department council. The Department, Faculty and University all work together in an organized way to guarantee the level of quality. Courses that have many sections must have a course leader, who is responsible for monitoring and keeping track of the educational process of other faculty members teaching other sections under his responsibility.

\section{SWOT ANALYSIS PROCEDURES}

SWOT analysis was performed by authors of this study after performing set of interviews with faculty members in all departments in KASIT, and the authors themselves are faculty members who participated in activities regarding both SWOT and QA issues in the faculty. And, also the results of SWOT tables of KASIT faculty were referred to in this study.

SWOT analysis manifests analytical view in order to meet the aims and objectives of KASIT, which is illustrated in Table-2.

A brief description and discussion of each element mentioned in TABLE-2 will take place in the following, starting with strengths attribute, weaknesses, then opportunities, and finally threats attribute.

TABLE II.

ILLUSTRATIVE DIAGRAM OF SWOT ANALYSIS AT KASIT

\begin{tabular}{|c|c|c|}
\hline & Helpful & Harmful \\
\hline & $\begin{array}{l}\text { Strengths } \\
\text { 1. Awareness to the require- } \\
\text { ments of educational proc- } \\
\text { ess and students. } \\
\text { 2. Choosing students whose } \\
\text { have ability and good } \\
\text { mentality. } \\
\text { 3. Using new technologies. } \\
\text { 4. School diversity. } \\
\text { 5. Specialized academic staff. } \\
\text { 6. Availability of specialized } \\
\text { library. }\end{array}$ & $\begin{array}{l}\text { Weaknesses } \\
\text { 1. Increased fees of credit hours } \\
\text { comparing with other facili- } \\
\text { ties. } \\
\text { 2. Small number of academic } \\
\text { staff. } \\
\text { 3. Competing priorities of time } \\
\text { according to students. } \\
\text { 4. Rivalry demands on aca- } \\
\text { demic staff' time. } \\
\text { 5. Delay of constructing } \\
\text { specialized library. }\end{array}$ \\
\hline 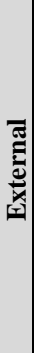 & $\begin{array}{l}\text { Opportunities } \\
\text { 1. Improving quality. } \\
\text { 2. Changeable education } \\
\text { environments. } \\
\text { 3. Using scholarship for } \\
\text { assisting recruitments. } \\
\text { 4. Competitive advantage. } \\
\text { 5. Going up the collection of } \\
\text { programs to face market- } \\
\text { place. }\end{array}$ & $\begin{array}{l}\text { Threats } \\
\text { 1. Population growth. } \\
\text { 2. Rapid technological change. } \\
\text { 3. Complex processes for } \\
\text { approvals on new programs. } \\
\text { 4. Uncertainty conditions. } \\
\text { 5. Regulation and legislations } \\
\text { of country. }\end{array}$ \\
\hline
\end{tabular}

A. Strengths:

1. Awareness to the requirements of educational process and students: All KASIT departments' programs provide students with opportunities to develop and demonstrate knowledge, understanding, cognitive/intellectual, and transferable skills. The outcomes were developed with reference to the Ministry of Higher Education in Jordan, the Mission of the University of Jordan, and QAA for Higher Education in England, and ACM specifications for Computing (2005) [5].

\section{- According to CDCO:}

a) The students of CS are providing with well organized curriculum design by providing them with a detailed curriculum map, supervisory plan at the first moment they entered to the department.

b) Starting from the study plan of the year 2002, the department has added the course entitled "Graduation project" to be obligatory course which enhances the abilities of students to cope with continuous changes of society needs. Also "training hours" in approved organizations is considered obligatory and is a graduation requirement.

c) On 2005, the total credit hours of the study plan were changed from 126 credit hours to 132 credit hours.

\section{- According to SSG:}

There are various preparations done at the beginning of each semester such as: students are distributed according to lists, to be supervised by the instructors in the Department during the withdrawal and addition week. Follow-up of course equivalents for students transferred from other universities to the University and admitted for bridging purposes, guide students in the registration process providing them with the needed academic consultations ... etc.

2. Choosing students whose have ability and good mentality: all KASIT departments accepted student whose have both ability and good mentality.

\section{According to SAP}

Students with several backgrounds may be accepted according to the regulations of the Ministry of Higher Education in Jordan; No student with an average less than $70 \%$ in the General High School Exams will be allowed to apply in Public Universities. However, JU records showed that the vast majority of the accepted students in KASIT departments were close to the average $90 \%$. Special needs students are taken into consideration.

3. Using new technologies: Learning resources that are used for the benefit of the CS, CIS, and BIS departments are part of the overall KASIT resources. These resources are available to all KASIT students. KASIT intended to use new technologies, and administrative staff who are capable to use these technologies, in order to improve the quality of learning outcome.

\section{According to LR:}

all KASIT departments are using various resources such as: KASIT Computer Labs, Computer Labs in other faculties, Special Internet Labs, The Computer Centre, 
Software Packages and Manuals, Online Courses, Blackboard facility, Moodle facility, E-Library and other resources... etc.

4. School diversity: KASIT departments are varied in the gender, ethnic, religion and in nationality background. On the other hand the departments also serve student with special-needs.

\section{According to TLA}

KASIT departments provide special class rooms for student with special-needs, it also provides teaching assistance for blind students.

5. Specialized academic staff: The academic staff members in the KASIT departments are engaged in teaching, research and consultation. All the deprtments employs qualified teaching staff members, with different ranks and specializations. Some of them have more than 20 years of teaching and research experience. Due to the diverse backgrounds in their specialization, common research projects were successfully conducted between the academic staff in the departments.

\section{According to TLA}

KASIT departments depend on many techniques for assessing teaching and learning for its students. First, the main methods used for teaching include: lectures, exams, and assignments, presentation methods including data show, laptop, and electronic material such as material on Blackboard, white boards, conference rooms, and smart boards. Teaching instructors include professors, lecturers, teaching assistants, lab supervisors. Second, the main methods used for learning include: laboratory incubator called the I-Lab, external lectures, training workshops, training in approved organizations, and graduation project.

6. Availability of specialized library: The progress in research is the key requirement for improving the quality of teaching. This needs for a specialized library in CS department.

\section{- According to LR}

The KASIT library which was constructed at 2008. According to JU Website [8], the last data update was on 22/04/2010, there are more than 101 journals and 1,222 academic books in IT related areas are located in the KASIT library within its building. Also, the main library provides a wide variety of reading material, including: 503,602 books, 71,410 master and PHD dissertations, 30,418 digital groups, and 57,221 references. In addition, at the end of each semester, all departments' chairmen in KASIT send requests for their academic staff to send a feedback of recommended readings to be added to the shelves of the library by placing orders for those readings. In addition, JU students and staff can access freely a lot of E-Journals and E-Databases by using the E-library Website which has a link in the official JU Web site [8].

\section{Strength (in general):}

\section{According to QME}

All of the above strengths must keep up with the Quality of Service needed to keep up in the minimum requirements of QA. In order to satisfy this, all of the above 5 strengths are measured and evaluated through the specialized committees, the needed budget, the field and financial studies are performed.

\section{B. Weaknesses:}

1. Increased fees of credit hours comparing with other faculties: The fees in all other scientific faculties in University of Jordan are lower than the IT faculty, which encourages the students to register in other faculties for lower fees, if they achieve the rules of registration.

\section{- According to SAP}

A lot of students are forbidden from studying IT because of high fees, even though their General High School JPA satisfies the conditions to register in KASIT.

\section{Small number of academic staff}

\section{According to TLA}

The permanent academic staff in CS department count are 4 females and 15 males, which is below the minimum QA standard the CS department tends to employ an average of 15 -20 part-time staff from related industry to help in teaching the University requirement courses in Computer Science and other specialized courses.

\section{Delay of constructing specialized library:}

As mentioned in Strengths attribute: 6, The progress in research is essential to improve the quality of teaching. In the contrary, the absence of specialized library in CS department and limited facilities to conduct research, besides the lack of systematic means of encouraging students' candid discussions with staff, will constrain the learning process.

\section{According to LR}

The KASIT library which was constructed on 2008. But, KASIT was constructed on 2000, which left the faculty without the specialized library for whole 8 academic years. Even though, students were able to use the facilities in the main library which served all the faculties of JU. In addition, many students referred to Faculty of Science Library and Faculty of Engineering Library. Both libraries provided the students with many articles and research topics located in journals and books related to both engineering and IT fields. But lack of specialized library was considered a weakness factor during that period of time.

4. Competing priorities of time according to students: Some of students' signs up for with a view to enhancing his career and professional life and to learning about new techniques adopted worldwide, they aim to enhance self-development or selfactualization. On the other side, they have social life, so they must make balance between their time and other things. Since the lectures time table is in between 8-5, and the labs are open for the same period.

\section{According to $\mathbf{L R}$}

Students face some weakness in the educational process, and they don't have a time to visit labs in order to develop their skills and capabilities at programming.

\section{Rivalry demands on academic staff' time:}

\section{According to QME}

There are various constraints face the academic staff which decreases the sustain development, such as: lectures, management works, supervision on graduate students, committee work. These constraints limit the selfdevelopment including research, conferencing, training workshops...etc. 


\section{Opportunities:}

1. Improving quality: The CS Department tends to use various methods and systematic evaluation strategy to assess the quality of outcome of the learning process, the quality of academic programs. So improving quality in CS Department is achieved according to:

\section{LR}

In KASIT, the human resources are shared by the three departments of the School. There are a variety of faculty members, both $\mathrm{PhD}$ and $\mathrm{M}$. Sc. holders, and teaching assistants. The department agrees with a number of Parttime staff members. Part-time staff members from the industry sector provide added value proficiency to develop the students' ability to expand the professional skills that are required in industry. Staffing remains a problem for the School although a good improvement made by JU by applying various changes to the employment procedures in order to attract new faculty members. The ratio of faculty members to students remains high and is a common problem in Jordanian universities. Despite all the efforts made by the University, the ratio remains high, but is manageable. The ratio will get better in the coming years since the university has granted many students Ph-D scholarships in UK, Korea, Italy, USA, and other countries' universities. The School also has adapted a policy to fix the number of newly admitted students to the School to reach the ratio of 1 faculty member to 20 students, recommended by QAA [3].

\section{QME}

The CS Department has the following main internal institutional entities; the department council, the chairman of the department, committees and course leaders in order to participate in managing and enhancing the quality to achieve their provision. The CS Department aims to meet new employment demands, and put evaluation strategy for the quality of teaching, the quality of academic programs and the competence and motivations of the faculty members in performing their academic duties.

\section{QME}

The rules and regulations of the University are rigorous and ensure realistic quality [8]. CS department also has a strong construction, where specialized committees undertake a thorough study for the various aspects and then submit a report to the Department council through the Department Chairman. The Department, Faculty and University all work together in an organized way to guarantee the level of quality.

\section{QME}

The administration of JU has built a specialized unit Called "Quality Assurance Unit" administrator by VicePresident for "QA Affairs". This unit has branches in all faculties in the university represented as a committee entitled with the same name.

\section{Changeable education environments: According to $\mathbf{L R}$}

The appearance of E-conferences, E-learning facilities, and Blended Learning yield to include these modern techniques in the plan of each teaching organization, including JU and CS department. So, Blackboard, Moodle, Academic Staff websites, and Automated Exams are day after day more activated and depended on in the teaching-Learning process in CS department. Also, the trends of graduation projects were aimed toward EApplication in all departments of KASIT.

\section{QME}

Technology can play a positive role in academic achievement, so developing information technology and systems of communications are changing the nature of educational process, and increasing the effectiveness of teaching. In other words, growing IT can reflective on the learning outcomes; this way can build kind of comparative advantage between nations.

\section{Using scholarship for assisting recruitments: \\ - According to TLA}

The CS Department is willing to have room for these increases, since 4 Ph.D. candidates on scholarship are at many universities in USA, UK, and Canada. Also, 4 of the current Ph.D. academic staff have gained their degrees in the same way. However, most of the new Ph.D. graduates in Computer Science prefer to work in private universities due to their attractive salaries compared to those offered by the University of Jordan.

\section{QME}

JU has embarked on a plan whereby additional scholarships are to be allocated to distinguished graduates from the CS Department to guarantee that they will work at the University of Jordan upon their graduation As teaching assistants for maximum 6 months in order to gain a Ph.D. degree acceptance, then JU grants them their full scholarship to finish their degrees.

\section{Competitive advantage:}

\section{According to QME}

Competitive advantages give a company an edge over its rivals and an ability to generate greater value for the firm and its shareholders. The more sustainable the competitive advantage, the more difficult it is for competitors to neutralize the advantage. The CS Department struggles to gain the competitive advantage in this field at the educational level, through differentiation advantage. That affects on the number of accepted students comparing with other universities which doesn't have the same program and specialization.

\section{Going up the collection of programs to face mar- ketplace:}

\section{According to QME}

The CS Department provides specialized counsel for governmental and private institutions interested in the areas of software development and office automation. This maintains a very good relationship between CS and the current market through consultancy, innovative ideas and training in computer-based developments and solutions in a global economic.

\section{Threats:}

\section{Population growth:}

\section{According to QME}

There are many aspects which impacts from the rapid population growth, such as: food, water, health, education, employment and environment. So, in this paper, the growth of population increases the demand of education in the country. On the other hand, the country suffering from the decreases of recourses and spending fewer budgets per child according to increasing numbers at primary schools. So, the quality of education at the secondary schools may 
be failed to achieve the goals of education and learning for all.

\section{LR}

The above threat will affect on the budgets of the government to support the universities needs for research, enhancing the available learning resources, and follow the financial plans for developing the learning-teaching process.

\section{Rapid technological change: According to QME}

Advancing technology threats the stability and competitiveness of organization. These threats may be unpredictable and unavoidable. So the countries must put plans to deal with it. For example: Jordan has made radical changed in there infrastructure.

LR: The University of Jordan takes in to account the power of IT to support learning and attracts an increasing number of students with its mixture of high quality teaching besides learning resources. In addition, University of Jordan aimed to and worked on employing academic staff with different specializations.

\section{Complex processes for approvals on new pro- grams:}

\section{According to QME}

The improving and developing new programs is hard to undertake, because this program must shape the criteria's of higher education besides the priorities of academic departments. To achieve this step, we need to collaboration and organization many items, such as: staff, committees, procedures and systems contained by University. On the other hand, innovative program need to endorsement from the commission of the ministry of Higher Education, this process need to year or two years to be achieved.

\section{QME}

Information on resource implications of the proposed program, including: long-term costs of the of the proposed program must be assessed, including those related to infrastructure changes necessitated by the program; and an assessment of urgent costs and how they will be addressed. In addition the confirmation of existence of a provincial and/or regional need for that program

\section{Uncertainty conditions}

\section{- According to QME}

There are various reasons affect the learning process at Jordan, in the last decay. For example: migraine and wars. These unstable conditions affect on the decisions of students' acceptance, which affect on the quality of final outcome of learning.

\section{Regulation and legislations of country: According to QME:}

The government's regulations and legislations are reflecting on the decisions of higher education. So the government attempt to capitalize on the growth of the IT and education sectors, via encouraging transfer these knowledge to other countries. That affects the availability of well trained and qualified holders of all different IT degrees.

\section{SAP:}

The above threat will affect on number of accepted registered students not only in the CS department but in all departments in all universities in Jordan.

\section{SUMMARY}

This paper has applied SWOT analysis technique on the CS Department at KASIT in University of Jordan. SWOT analysis was performed according to the criteria for Quality Assurance Procedures in higher education and training. As the study shows in the above discussion, many SWOT attributes interact with QA procedures regarding CS department.

More precisely, Strengths SWOT attribute can be evaluated according to CDCO, LR, TLA, SSG, SAP, and QME procedures of QA. While, Weaknesses attribute is evaluated according to TLA, LR, SAP, and QME procedures. And, Opportunities attribute can be evaluated according to TLA, LR, and QME procedures. Finally, Threats attribute can be evaluated according to LR, SAP, and QME procedures.

As observed above, the most common interacted QA procedure was LR in all SWOT attributes. This shows that Learning Resources (LR) attribute has a great role in enhancing and evaluating any education system in universities. If reader reviews the Threats attribute, he/she will find that the most repeated procedure was QME. This means that the greatest dangerous threats come from keeping up the level of Quality to satisfy the needed conditions. Also, it can be noted that the Strengths attribute has the largest number of QA procedures; it interacts with them all. This means that the CS Department system has satisfied all the required QA procedures for the Strengths attribute.

\section{REFERENCES}

[1] Barker, K.(2002), ePortfolio: A Tool for Quality Assurance, FuturEd Consulting Education Futurists Inc. Vancouver, Canada. Retrieved from http://www.futured.com/library.htm

[2] Fine, L., (2009). The SWOT analysis: Using your strength to overcome weaknesses, using opportunities to overcome threats. ISBN-10: 1449546757.

[3] Institutional review of higher education institutions in England and Northern Ireland: A handbook for higher education providers(2nd ed).(2011).QAA publications, UK. ISBN:978 184979255 4.

[4] Lucas, M., (2000).Understanding business: Environments. (1st ed). Routledge. ISBN-10: 0415238609.

[5] Shackelford, R., McGettrick, A., Sloan, R., Topi, H., Davies, G., Kamali, R, Lunt, B. (2005). Computing Curricula 2005, the Overview Report. ACM and IEEE Computer Society, USA,456-457. ISBN: 1-59593-359-X.

[6] Stapleton, L., E., \& Stemler, L., (2005). S.W.O.T. Your curriculum: MIS curriculum assessment at a small Midwest University. 38th MICS (Midwest Instruction and Computing Symposium), University of Wisconsin-Eau Claire, Eau Claire, WI, USA.

[7] The quality assurance agency for higher education (QAA) website. (2001). Retrieved from http://www.qaa.ac.uk/Pages/default.aspx

[8] University of Jordan official web site. (2011). Retrieved from http://www.ju.edu.jo

[9] University of Houston Victoria SWOT analysis: strength, weaknesses, opportunities and threats, annual report. (n.d.). Retrieved from http://www.uhv.edu/

[10] Webster, M., Online dictionary, quality assurance. (2011). Retrieved from http://www.merriam-webster.com/info/webster. $\underline{\mathrm{htm}}$

[11] Wikipedia Website. (2011).Retrieved from http://en.wiki pedia.org/wiki/SWOT_analysis 


\section{AUTHORS}

Lubna M. Nasir Eddeen is a teacher in Computer Science department in king's Abdullah II School for Information Technology at University of Jordan. She earned her Master degree in Computer Science from the University of Jordan, Amman, Jordan in 2004. She has published or in the process of publishing several research papers on image processing, security, and E-learning. She has also published a book on applications of Information Technology on education. She may be contacted at e-mail: Lubna@ju.edu.jo.

Ansar Magdalena H. Khoury is a teacher in Computer Science department in king's Abdullah II School for Information Technology at University of Jordan. She earned her Master degree in Computer Science from the University of Jordan in 1998. She has published or in the process of publishing several research papers on image processing, and E-learning. She may be contacted at email: ansar@ju.edu.jo.

Osama K. Harfoushi is an assistant professor in Business Information Systems department in king's Abdullah II School for Information Technology at University of Jordan. . He earned his Ph. Degree in Computer Science from University of Bradford, United Kingdom, in 2008. He has published or in the process of publishing several research papers. He may be contacted at e-mail: o.Harfoushi@ju.edu.jo.

Itaf Abu Shanab is an administrative assistant in king's Abdullah II School for Information Technology at University of Jordan. . She earned her B.Sc. degree in Business Administration / system track from Arab Open University, in 2008. She has many interests in publishing on Elearning, Business Administration, Sustainability, and HR Management. She may be contacted at e-mail: i.abushanab@ju.edu.jo.

Nabeel M. M. Alassaf is a teacher a teacher in Computer Science department in king's Abdullah II School for Information Technology at University of Jordan. He is also University of Jordan Hospital director assistant for computer affairs He earned master degree from university of Jordan in 2005. His research interests (Algorithms, Discrete Math, programming language, networks especially in mobile agent communication). He may be contacted at Email: n.alassaf@ju.edu.jo.

Received 12 March 2012. Published as resubmitted by the authors 11 January 2013. 